\title{
Development and performance evaluation of pedal operated dehuller for black soybean
}

\author{
Gurupreet Singh and Khan Chand
}

Received : 28.07.2020; Revised : 24.08.2020; Accepted : 26.09.2020

See end of the Paper for authors' affiliation

Correspondence to :

Khan Chand

Department of Agricultural

Engineering, School of

Agricultural Sciences and

Rural Development, Central

University of Nagaland,

Medziphema, Dimapur

(Nagaland) India

Email:kcphpfe@gmail.com
-ABSTRACT : Black soybean is a food source which contains high quality protein and does not contain cholesterol and saturated fatty acids. It is rich in vitamin and minerals and has significant medicinal effect. In India, traditional method of dehusking the black soybean is hand operated grindstone (Chakki). In grindstone, main disadvantage is the incomplete dehulling of the beans. This method of dehusking is also tedious and time consuming process. Therefore post harvest management and processing of black soybean are very important and hence an effort has been made to develop a pedal operated dehuller for Uttarakhand women with the help of anthropometric data. Dehuller works on the principle of shearing force where black soybean passes through between the grind stone roller and concave surface of perforated mild steel sheet and power would be provided through pedal to the machine. The different components were designed and best dehulling efficiency of the machine was 72.08 per cent at 10 per cent moisture content and $25 \mathrm{~kg} / \mathrm{h}$ feed rate with payback period of 1.67 year. This machine is basically designed for Uttarakhand small women farmers and can generate employment.

- KEY WORDS : Black soybean, Pedal operated machine, Design components, Payback period

- HOW TO CITE THIS PAPER : Singh, Gurupreet and Chand, Khan (2020). Development and performance evaluation of pedal operated dehuller for black soybean. Internat. J. Agric. Engg., 13(2) : 245-251, DOI: 10.15740/HAS/IJAE/13.2/245-251. Copyright@2020: Hind Agri-Horticultural Society. 